\title{
The Federal Budget and Stabilization Policy in 1968
}

HE FEDERAL BUDGET and the Economic Report of the President are presented to Congress and the public early each year. Together they can be viewed as a national "economic plan" in the spirit of the Employment Act of 1946. ${ }^{1}$ The purpose of this article is to summarize and analyze the economic plan for 1968. Emphasis is placed on fiscal actions required to achieve the goals of high employment with relative price stability and equilibrium in the balance of international payments.

The 1968 national economic plan calls for a gross national product of $\$ 846$ billion, a 7.7 per cent increase over 1967, consisting of 4.2 per cent growth in real product and 3.4 per cent increase in prices. The chief economic problem in 1968, as expressed by the President's Council of Economic Advisers (CEA), is to restrain the increase in dollar demand for goods and services to a limit imposed by growth in the nation's potential to produce. To deal with the problem of potential excess demand, the CEA recommends a 10 per cent surcharge on corporate and individual income taxes, effective January 1 for corporations and April 1 for individuals. The CEA warns that in the absence of fiscal restraint, the economy will be subject to serious inflationary pressures and/or serious financial stringency.

Errors in past national economic plans and the prospects of success for future plans depend crucially on information regarding three areas of economic knowledge. One concerns the quantitative effect of fiscal and monetary actions on total demand; a second, the timing of the effects of fiscal and monetary actions on total demand; and a third, the trade-off between prices and real output.

\section{Stabilization Policy and Economic Performance in 1967}

As background for the analysis of the national eco-

\footnotetext{
1 The term, "economic plan", follows from the idea that given certain information about the structure of the economy and assumptions about the course of monetary actions, total demand can be controlled at the margin by fiscal actions. Use of the term, "economic plan," does not mean to imply that allocation of the nation's output to particular sectors is planned.
}

nomic plan for 1968, economic conditions and stabilization policies in 1967 are reviewed. The CEA's economic plan of a year ago is compared with the outcome.

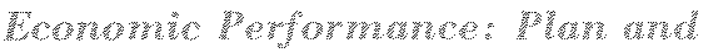

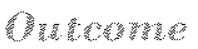

On balance, economic activity advanced in 1967 but at a much slower rate than in recent years. The year's growth pattern consisted of a sluggish first half followed by a sharp acceleration in the second half. The slowdown in the first half was dominated by a large inventory adjustment which more than offset the increase in final demand, whereas the second half was influenced primarily by a sharp turn-around in the rate of inventory accumulation, even though final demand slowed.

Superficially, the CEA's plan for 1967 appears to have come very close to being realized, although the pattern during the year was more uneven than anticipated. The advance of activity in the first half was much slower than planned, while that of the second half was apparently faster than planned. In retrospect, the first-half slowdown was clearly underestimated by the CEA, but the second half surge was apparently misgauged because the major restraining fiscal actions planned were not implemented.

In retrospect, it appears that the CEA forecast the composition of GNP very accurately (Table I). In terms of absolute error the major exception was con-

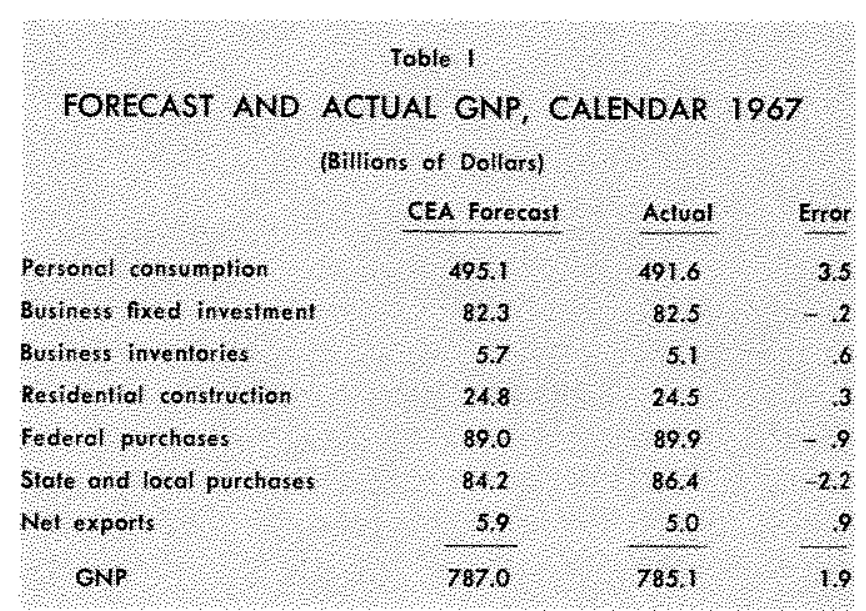


sumption, which was lower than forecast. The low estimate occurred even though the recommended tax surcharge was not implemented. A proper appraisal of the CEA forecast should be based on a comparison of its forecast, without a tax surcharge, with the actual outcome. The surcharge, as originally proposed, was designed to produce about $\$ 3$ billion in revenue; thus it could probably be assumed that the CEA was forecasting a GNP in the $\$ 790$ to $\$ 793$ billion range in the absence of the surcharge. On this basis, the CEA's GNP forecast was in error by $\$ 5$ to $\$ 8$ billion.

A forecast of GNP is incomplete unless it is accompanied by an estimate of how the increase translates into real product and prices. The CEA's plan for 1967 included a 4 per cent increase in real product and a 2.5 per cent advance in prices. The record for the year indicates a 3.8 per cent growth in real product and a 3.2 per cent rise in prices.

The comparison of plan with outcome regarding output and prices is blurred by the fact that the CEA's plan assumed a tax increase. The CEA underestimated the extent to which inflationary forces were operating in 1967. A larger portion of the 1967 increase in GNP went into prices than in any other year since 1958.

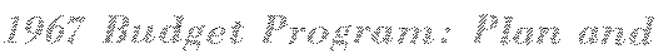

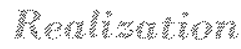

In January 1967 the CEA presented its budget program for the year. A key part of that program was the proposed surcharge on income taxes to take effect on July 1 . The budget plan called for a $\$ 4$ billion deficit in the national income accounts for calendar 1967 . The actual deficit is currently estimated at $\$ 12.6$ billion. A comparison of planned and actual receipts and expenditures is shown in Table II.

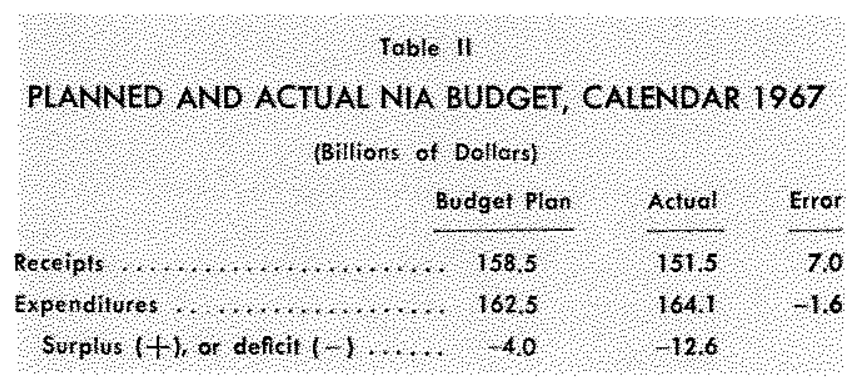

The chief reason for error in the budget plan for last year was the failure to estimate receipts accurately; actual expenditures exceeded the forecast by only $\$ 1.6$ billion. The shortfall of receipts can be explained by two factors: (1) the failure of Congress to take action on the surcharge, and (2) the slower-than-expected

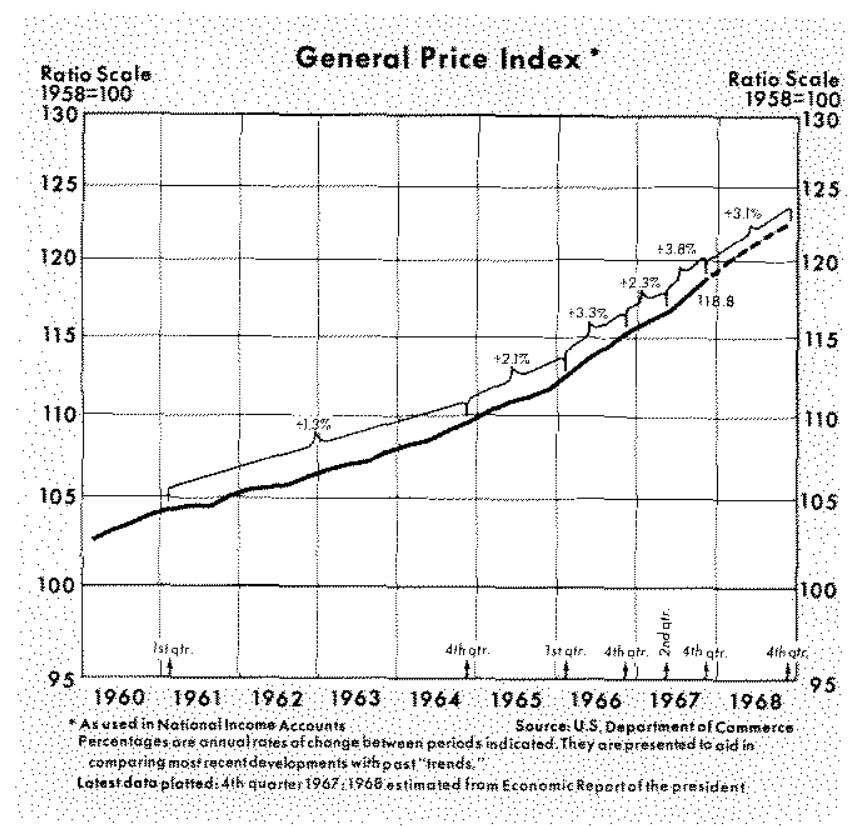

rise in economic activity, especially in the first half.

The 1967 experience suggests the desirability of the CEA presenting publicly, when relevant, several forecasts based on alternative sets of assumptions. For example, in 1967 it would have been informative if the CEA had presented in detail two forecasts, one assuming the tax surcharge and the other not. In this way Congress and the public would have been better able to assess the consequences of Congressional action or inaction.

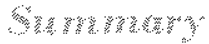

The year 1967 was a year of moderate growth, despite fiscal actions that were more expansionary than planned. Monetary actions were very restrictive in late 1966 and probably affected economic expansion in early 1967, but during 1967 monetary expansion was probably more rapid than anticipated. The 1967 CEA report implied that monetary restraint would be required if fiscal restraint, through the surcharge, was not forthcoming. This policy alternative was not placed into operation. Even though the surcharge was not enacted, causing fiscal actions to be more expansionary than planned, monetary actions remained stimulative through December 1967.

Despite the continuing stimulus from fiscal actions during 1967, economic activity was sluggish in the first half and ebullient in the second. This experience demonstrates the operation of lags in the economic impact of monetary and fiscal actions. The first-half slowdown of activity probably reflected the restrictive monetary actions of 1966, which more than offset the fiscal stimulus of that period. It was not until the 
second half of 1967 that the economy reflected the combined stimulus of fiscal and monetary actions.

In retrospect, the sequence of economic events took place under such a different set of circumstances than the CEA anticipated in its forecast, that it is not very useful to compare their plan with the outcome. It would seem to be in the public interest to have the regime of circumstances outlined more explicitly, enabling a more enlightened decision-making process with regard to stabilization policy.

\section{Budget Program for 1968-69}

The budget program for fiscal 1969 is presented within a new format. A new concept of the budget is presented, which replaces the outmoded and midleading administrative budget and removes some confusion arising from the use of several budget concepts.

The budget plan of the Federal Government for fiscal 1969 (year ending June 30, 1969) calls for a deficit of $\$ 8$ billion in the new unified budget. ${ }^{2}$ Expenditures are scheduled to rise 6 per cent from fiscal 1968 and receipts by 14 per cent. The deficit for fiscal 1968 is estimated at $\$ 20$ billion.

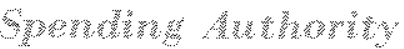

Spending authority (i.e., budget authority in the official parlance of the budget report) for fiscal 1969 is scheduled to rise by 8.2 per cent, compared with a 2.2 per cent increase in the previous fiscal year. An 8 per cent increase in authority for defense, international and space is included, compared with a 1 per cent increase in the previous fiscal year. Authority for domestic programs increases about 9 per cent, up sharply from the 4 per cent rise in fiscal 1968.

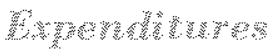

Although spending authority is scheduled to rise more rapidly in fiscal 1969 than in fiscal 1968, expenditure plans indicate a marked slowdown in the rate of increase. The fiscal 1969 budget plans a 6 per cent rise of total spending, consist-

\footnotetext{
- Since the budget plan is always prepared on a fiscal year basis, i.e, for the year ending on June 30 , the budget plan is summarized on this basis. The following section on the economic impact of the budget focuses on calendar 1968. Budget plans for the calendar year have to be pieced together from the budget report and the CEA report.
}

ing of 4 per cent for defense, international and space, and 8 per cent for domestic programs. Increases in spending for these programs are estimated at 9 and 14 per cent, respectively, in fiscal 1968.

Estimates of defense spending for fiscal 1969 imply a leveling off in defense purchases. When adjusted for changes in prices, the increase translates into little change in real terms. Any expansion in U.S. military commitments would require supplemental appropriations not included in the budget.

The increase in domestic spending primarily reflects programs that have already been legislated. Increased social security benefits are scheduled for March and a pay raise for Government employees for July. Expenditures for education, housing, etc, however, are scheduled to be cut back by 4 per cent.

The discrepancy between changes in budget authority and expenditures indicates that the pool of authorized and spendable funds is being drawn down substantially in fiscal 1968, but is scheduled to be built up in fiscal 1969.

\section{mections}

Federal receipts are estimated to rise sharply in fiscal 1969, reflecting a 10 per cent surcharge on cor-

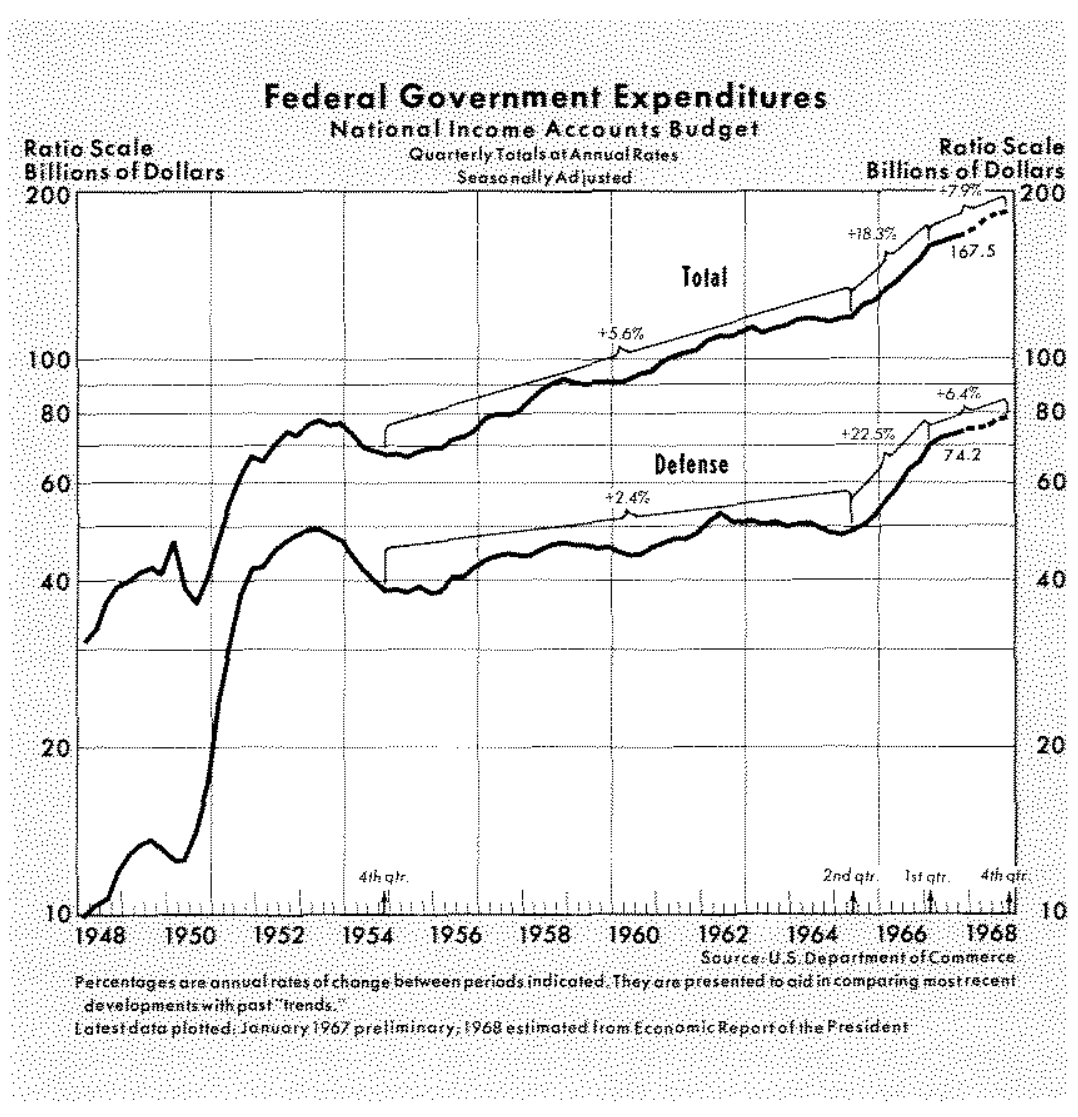


porate and individual income taxes, effective January 1 for corporations and April 1 for individuals, The surcharge would provide an estimated $\$ 9.8$ billion in fiscal 1969.

Other features of the tax program include expansion of the base for social security taxes in calendar 1968, an increase in social security tax rates on January 1 , 1969, and extension of excise tax rates on telephone service and automobiles. The increase in the social security taxes will add $\$ 3.3$ billion to revenue. Extension of excise rates, which under existing laws are scheduled for reduction on April 1, will prevent the loss of $\$ 2.7$ billion.

Changes in tax laws are estimated to add $\$ 10.8$ billion in revenue in fiscal 1969 . The remaining $\$ 11.5$ billion of the increase is expected from growth in the economy.

\section{Federal Budget Actions and the Economic Outlook for 1968}

Proposed budget actions for the eighteen-month period ending June 30,1969 , rest on the premise that in the absence of actions to raise tax rates or restrain monetary growth, federal budget actions would be overly stimulative in relation to present and expected strength of private demand relative to productive capacity. The budget program will probably have little effect on the rate of economic expansion early in calendar 1968, since the effect of most tax actions would not be felt by consumers until spring. Instead, the program apparently aims at achieving a more moderate expansion in the second half of 1968.

The CEA's forecast for 1968 has built into it a 3.4

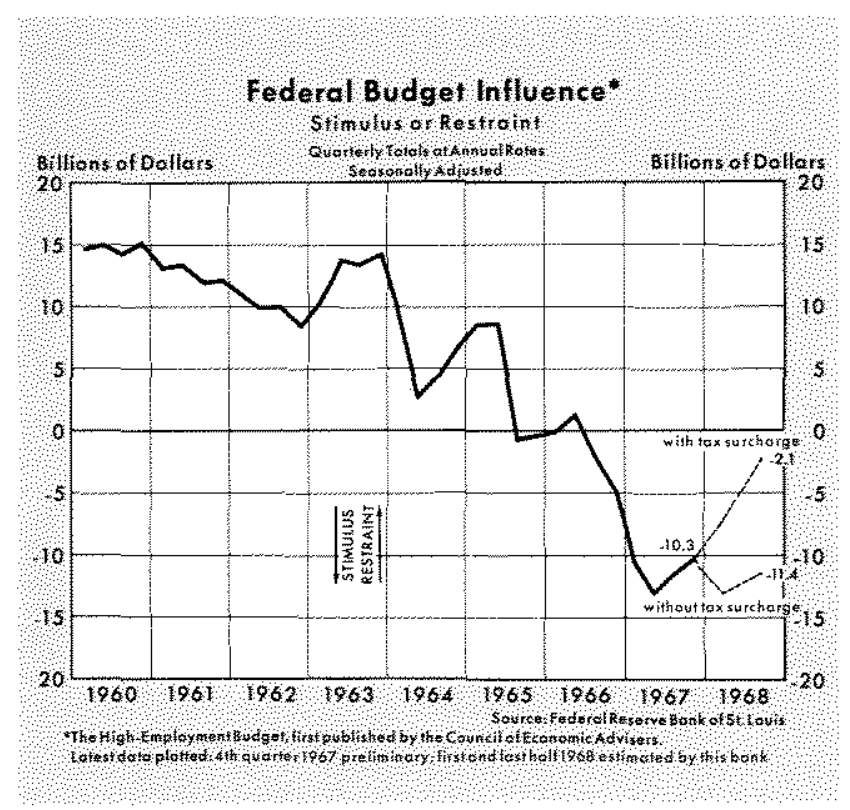

per cent increase in prices. This increase, if realized, would be the largest year-to-year change since 1957 . Compared with the experience of other periods since 1965 (when the economy reached full employment), the projected increase in prices appears to be roughly consistent with the 7.7 per cent forecast increase in total demand (see Table III). There is no indication

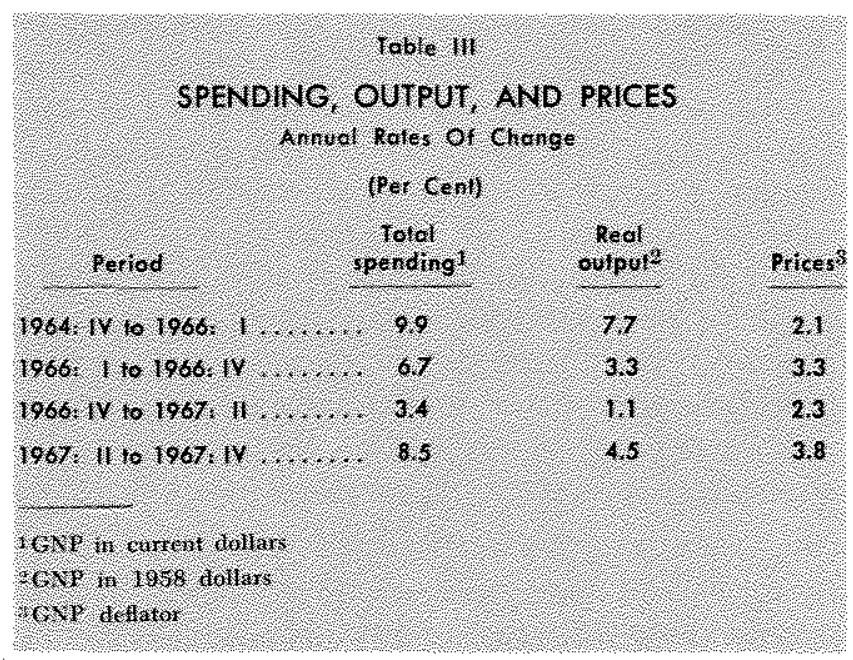

in the CEA report, however, as to whether this combination of output growth and price increase is the most desirable of the attainable alternatives. It would be of great help to the policymakers if the CEA had provided their alternative estimates of real product growth and inflation rates for different target levels of total demand. In this way Congress and the public would be in a better position to judge whether the CEA's economic plan is the best attainable under the circumstances. Little is known about the trade-off between output and prices, yet the public would be benefited if it knew the CEA's assumptions about this trade-off. ${ }^{3}$

\section{Wromon}

Economic activity is rising rapidly, fueled by the lagged effects of a large fiscal stimulus and very rapid monetary expansion in 1967. The deficit in the highemployment budget was estimated at $\$ 10$ billion in the fourth quarter, compared with a $\$ 5$ billion deficit a year earlier. The nation's money supply rose 7 per cent from December 1966 to December 1967, the fastest rate for a twelve-month period since World War II.

\footnotetext{
"It has been suggested that there is both a short-run and longrun trade-off between output and prices. For an attempt to estimate these trade-offs for several countries, see Michael Keran, "The Effect of Total Demand on Real Output," Federal Reserve Bank of St. Lovis Review (July 1966), pp. 7-12.
} 
These past policy actions are currently working to overheat the economy. Since policy actions affect the economy with a lag, there is perhaps little that can be done to restrain inflationary forces effectively in the first half of 1968. To avoid the cumulation of these inflationary forces, however, restrictive actions should be taken promptly. The fiscal program was supposedly designed for this purpose.

The question remains whether the proposed actions are sufficient to successfully combat inflation, Relevant in answering such a question is the expected course of monetary actions. With more restrictive fiscal actions it would be easier to restrain monetary growth, and, although it remains silent on this point, it is likely that the CEA expects slower monetary growth. If monetary actions continue to be expansionary, any restrictive effects flowing from the fiscal program may be negated. If monetary growth is reduced, the combined fiscal and monetary program can probably be made effective.

The CEA does not spell out the requirements for monetary action in its economic plan, but the success of the program depends crucially on monetary growth. In addition, the possible consequences of Congressional inaction on the surcharge deserve a thorough examination.

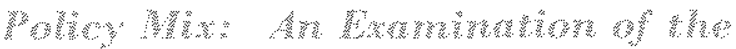

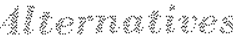

Answers to such questions as posed above require quantitative estimates of the impact of fiscal and monetary actions. Such estimates require information about the structure of the economy. There is little general agreement among economists about this structure, yet an implied structure of the economy underlies the CEA's economic plan. Since the CEA does not make its economic model available to the public, the results of other studies have to be used to examine in greater detail the implications of the budget plan for economic activity in 1968.

The CEA emphasizes that failure to enact the surcharge would leave the entire burden of stabilization to the Federal Reserve. More properly, it might be said that the burden of stabilization, assuming the Federal Reserve restricts bank credit to the rate consistent with desired growth in total demand, will be greatest on those who rely most heavily on credit, especially longterm credit. The consequences will be a severe strain on financial markets with possible disruptive effects on the housing sector. The CEA's statements are qualitative; no quantitative estimates of the effects of this policy alternative are given.
Econometric studies have been conducted over the years, however, which shed light on this trade-off between fiscal and monetary actions. Table IV provides some crude estimates of the effects of the proposed tax surcharge, as obtained from one such model. ${ }^{4}$ It should be emphasized that other models would give different results.

These estimates are prepared on the assumption that GNP totals the same $\$ 846$ billion as the CEA projects in its report, and that the Government's spending plans will be realized. Given these assumptions, two sets of values are calculated-one showing the results with the surcharge, and the other the results without the surcharge. The difference between these two sets of values is shown in Table IV.

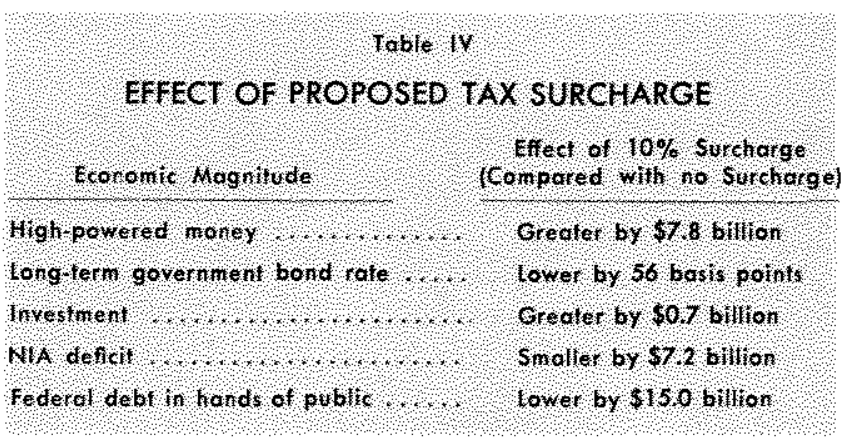

If the sturcharge is not passed, a larger deficit will have to be financed than otherwise. Also, monetary actions will have to be modified accordingly to achieve the GNP target. It is estimated that the proposed tax surcharge is the equivalent of $\$ 7.8$ billion in monetary action as measured by the change in high-powered money, i.e, bank reserves and public holdings of currency. ${ }^{.5}$ Thus, without the surcharge, the rate of monetary growth would have to be cut substantially to achieve the GNP target of $\$ 846$ billion.

Interest rates would be 56 basis points higher without the surcharge than with it, and as a result invest ment would be about $\$ 0.7$ billion less. The item most affected by the tax situation is the public's holding of Government debt, which would be greater by $\$ 15$ billion if no action is taken on the surcharge.

These estimates are crude, and are meant to be illustrative rather than indicative of actual magnitudes.

\footnotetext{
4 Based on estimates from a model similar to that presented by Professor Carl Christ before the December 1966 meetings of the American Economic Association. A detailed derivation of these estimates, along with estimates from alternative models, is provided in a memorandum entitled, "Policy Mix and the 1968 Economic Report," avallable on request from the hesearch Department of this Bank.

${ }^{5}$ See Leonall C. Andersen, "Three Approaches to Money Stock Determination," Federal Reserve Bank of St. Lotis Review (October 1967), pp. 6-13, for a description of this measure.
} 
Nevertheless, they are offered to demonstrate the interdependence of fiscal and monetary actions. Although existing estimates are approximate, they would seem to be more meaningful than intuitive judgment. If the consequences of inaction on the surcharge are not spelled out clearly, policymakers are not being sufficiently equipped with information upon which to make intelligent decisions.

\section{Conclusion}

The CEA's report has reflected increasing economic sophistication in recent years with regard to the formulation of stabilization policy. Many areas of economic knowledge are still in a sorry state, and the CEA continues to prepare its analysis on the basis of fiscal policy, largely ignoring monetary effects. Yet, there is little question but that the formulation of economic policy has improved over the years. One of the great problems that remains is the formation and im- plementation of policy when the economy is operating at high employment. According to Professor Walter Heller, former chairman of the CEA:

... the margin for error diminishes as the economy reaches the treasured but treacherous area of full employment. Big doses of expansionary medicine were easy-and safe-to recommend in the face of a $\$ 50$ billion gap and a hesitant Congress. But at full employment, targets have to be defined more sharply, tolerances are smaller, the line between expansion and inflation becomes thinner. So in a full employment world the economic dosage has to be much more carefully controlled, the premium on quantitative scientific knowledge becomes far greater, and the premium on speed in our fiscal machinery also rises. ${ }^{6}$

6Walter W. Heller, New Dimensions of Political Economy (Cambridge: Harvard University Press, 1966), pp. 69-70.

Keith M. Careson

\section{APPENDIX Measures of the Budget}

The new unified budget is introduced as a replacement for other outmoded measures. To gain an understanding of the new budget, the old budget concepts are summarized along with the new.

\section{Administrative Budget}

Prior to the presentation of the fiscal 1969 budget, the administrative budget was the basic planning document of the Federal Government. This measure of the budget included receipts and expenditures of funds owned by the Government, excluding funds held in trust.

\section{Cash Budget}

The cash budget measures the flow of transactions between the Federal Government and the rest of the economy. In addition to the activities included in the adminis - trative budget, receipts and expenditures of the trust funds and Government-sponsored agencies are included. Surpluses or deficits in the cash budget indicate changes in cash borrowing from the public and/or changes in the Treasury's cash balance.

\section{Unified Budget}

The new budget is a unified comprehensive statement of the Government's financial plan, replacing the administrative budget as the Government's basic planning document. The unified budget, as first presented, resembles most closely the cash budget, with the major difference being the treatment of sales of participation certificates in Govermment owned financial assets. The cash budget includes such sales as an offset to expenditures, whereas in the unified budget such sales are treated as borrowing. 
After accounting procedures are revised, receipts and expenditures in the unified budget will be presented on an accrual basis, rather than on a cash basis.

\section{National Income Accounts Budget}

The national income accounts budget summarizes the receipts and expenditures of the Federal Government sector as an integrated part of the recorded activities (i.e., the national income accounts) of all sectors of the economy. Primary differences between the national income accounts budget and the unified budget (and the cash budget) are (1) on the expenditure side, spending is recorded when delivery is made to the Government, and purchases and sales of existing real and financial assets are excluded, and (2) on the receipts side, taxes are in large measure recorded when the tax liabitity is incurred.

\section{High-Employment Budget}

The high-employment budget is an estimate of the national income accounts budget which would prevail at a specified constant rate of resource use. By eliminating the major built-in stabilizer effects (i.e., the effect of changing levels of economic activity on Government receipts and expenditures), the high-employment budget indicates the economic impact of changes in tax laws and legal provisions for expenditures.

\section{Budget Authority}

Budget authority is legislation by congress permitting a Government agency or department to commit or obligate the Government to pay out money either in the form of expenditures or loans. Congress does not vote on expenditures; it determines budget authority. Before funds can be spent or loaned, an agency must submit and have approved by the Bureal of the Budget an apportionment request. This determines the rate at which budget authority can be used. An agency usually incurs obligations, i.e., commits itself to spend or loan money, after apportionment by the Bureau of the Budget.

Incurring obligations does not necessarily mean immediate disbursement of funds. Trends in budget authority, however, are indicative of trends in expenditures, although frequently budget authority and expenditures diverge sharply on a year-to-year basis.

औ.

UBSCRIPTIONS to this bank's REvIEW are available to the public without charge, including bulk mailings to banks, business organizations, educational institutions, and others. For information urite: Research Department, Federal

Reserve Bank of St. Louts, P. O. Box 442, St. Lotis, Missouri 63166. 